\title{
Research toward Mobbing: Mobbing Perception in Northern Cyprus Tourism Sector
}

\author{
Almaz Sandybayev \\ Faculty of Business Administration, University of Mediterranean Karpasia, Kyrenia, Northern Cyprus \\ *Corresponding Author: almaz.sandy@akun.edu.tr
}

Copyright (C) 2015 Horizon Research Publishing All rights reserved.

\begin{abstract}
Tourism and recreation are parts of human life environment. A particularly important role is taken by hospitality and tourism service providers employing various groups of employees. However, the work environment is not always comfortable and includes factors that have a negative impact on mental development of the personnel. One of these factors is mobbing. The survey has been conducted in the hospitality sector which indicates a significant growth of mobbing among a group of hotel employees in Northern Cyprus by using quantitative research approach. Negative Acts Questionnaire (NAQ Scale) was used for analysing the level of mobbing. Thus, 360 participants were assessed by a questionnaire. The results have proved that mobbing within sample groups is widespread and seriousness of the problem of mobbing confirms not only the degree of its distribution but also the severity of its consequences for the individual.
\end{abstract}

Keywords Mobbing, Hotel Employees, Northern Cyprus

\section{Introduction}

The role of human resources has significantly increased which is considered as the main carrier of knowledge and skills. As a result, the management's targets qualitatively expanded to managing employees and their knowledge. In this regard, there was a need to form a new approach to human resources management that meets the requirements of the current economic paradigm and create conditions for the effective functioning of organizations.

At all levels, organizations and companies are tendered to administer a universal manpower to gain sustainable expansion and growth. However, the modern development of society is characterized by growing tensions in social interaction and sudden economic changes, determining the formulation and solution of the psychological safety within social environment of the organization as one of the most important and urgent today. Changes in the conditions of professional activity in the twenty-first century lead to the understanding of re-thinking approaches and forms relating to the successful and efficient collaboration in the social environment.

It is assumed that every person at least once in life faced with psychological violence in the social setting in the form of inadequate management requirements, negative psychological climate, management leadership style, unfair performance evaluation, the threat of dismissal, etc. According to World Health Organization [23], the number of people exposed to psychological violence at work is growing.

Heinz Leymann [18], for the first time introduced the concept of mobbing in psychological research specifying it as a type of violence. In Leymann's initial works, psychological violence and more specifically mobbing is realized similar to murder or robbery. The consequences of mobbing primarily affect the health and mental state.

Mobbing is not a single action and is considered as a process. The object of mobbing is personality which is under mobbing-action, or a person who is subjected to mobbing. The subject of mobbing is an actor of mobbing of action. Along with the objects and subjects, there is also a group of mates or associates which do not express an activity and therefore do not believe they are involved in the mobbing and do not bear responsibility for it. An employee who is present in the situation of mobbing attacks directed against colleagues and not interfering, thus supports the mobbing-action and also is responsible for it. Mobbing process has a clearly negative development. A number of authors describe different definitions of mobbing in the meaningful context according to the matrix attached. As seen, a phenomenon of mobbing has been widely researched.

Despite the extensive disposition and role of HRM, the topic of mobbing as a type of violence is rarely reflected in the Northern Cyprus HRM practices, particularly in the practice of hospitality companies. They continue to be guided by the inherent directive approaches and transactional management style. However, the new economic paradigm of the knowledge economy requires improvement of existing approaches to motivation and development of staff. 
Matrix 1. Mobbing Context

\begin{tabular}{|c|c|l|}
\hline $\begin{array}{c}\text { Act } \\
\text { Workplace } \\
\text { harassment }\end{array}$ & Author and Source & \multicolumn{1}{c|}{ Definition } \\
\hline $\begin{array}{c}\text { Workplace } \\
\text { bullying/mobbing }\end{array}$ & Einarsen et al.[13] & $\begin{array}{l}\text { "Repeated activities, with the aim of bringing mental (but sometimes also physical) pain, and directed } \\
\text { towards one or more individuals who, for one reason or another, are not able to defend themselves". } \\
\text { order for the label bullying to be applied to a particular activity, interaction or process, it has to occur } \\
\text { repeatedly and regularly (e.g. weekly) and over a period of time (e.g. about six months)". }\end{array}$ \\
\hline Emotional abuse & $\begin{array}{c}\text { Keashly \& } \\
\text { Jagatic.[15] }\end{array}$ & $\begin{array}{l}\text { "Interactions between organizational members that are characterized by repeated hostile verbal and } \\
\text { nonverbal, often nonphysical behaviors directed at a person(s) such that the target's sense of } \\
\text { him/herself as a competent worker and person is negatively affected". }\end{array}$ \\
\hline $\begin{array}{c}\text { Workplace } \\
\text { incivility }\end{array}$ & $\begin{array}{l}\text { Anderson \& } \\
\text { Pearson.[2] }\end{array}$ & $\begin{array}{l}\text { "Low-intensity deviant behavior with ambiguous intent to harm the target, in violation of workplace } \\
\text { norms for mutual respect. Uncivil behaviors are characteristically rude and discourteous, displaying a } \\
\text { lack of regards for others". }\end{array}$ \\
\hline $\begin{array}{c}\text { Victimization } \\
\text { Aquino et al.[3] }\end{array}$ & $\begin{array}{l}\text { "Individual's perception of having been exposed, either momentarily or repeatedly, to the aggressive } \\
\text { acts of one or more other persons". }\end{array}$ \\
\hline $\begin{array}{c}\text { Workplace } \\
\text { aggression }\end{array}$ & Baron.[17] & $\begin{array}{l}\text { "Any form of behavior directed by one or more individuals in a workplace toward the goal of harming } \\
\text { one or more others in that workplace (or the entire organizations) in ways the intended targets are } \\
\text { motivated to avoid". }\end{array}$ \\
\hline $\begin{array}{c}\text { Abuse } \\
\text { Interpersonal } \\
\text { deviance }\end{array}$ & $\begin{array}{l}\text { "Harmful behaviors directed towards coworkers and others that harm either physically or } \\
\text { psychologically through making threats, nasty comments, ignoring the person, or undermining the } \\
\text { person's ability to work effectively". }\end{array}$ \\
\hline
\end{tabular}

\section{Methodological Approach}

It is in particular crucial considering the fact that the research is understood from interdisciplinary standpoint nature and the study searches to investigate mobbing phenomena that is concerned by institutional organizations and social influences. This approach contributes for creating a base and guidance to the researcher. While, research design is the logical sequence that connects the empirical data to a study's initial research questions and, ultimately, to its conclusions [24].

\section{A. Population and Sampling Size Measure}

Considering statistical data received [19], the current number of employees in Northern Cyprus, 5 stars hotel establishments is 3.738 for 127 total establishments (incl.1-5* hotels). Thus, in total, selected 12 hotels officially employ 1280 employees which is used as a target population of the research. For this reason, the level of precision was considered: confidence interval (margin of error) and confidence level. The margin of error was $5 \%$ and the $95 \%$ confidence level mean that $95 \%$ can be certain.

For 1280 employess ( $95 \%$ confidence level \& 5\% error) 296 sample size (at least) is required (Matrix 2). The researcher proposed that larger number of questionnaires distributed than 296 will be effective in case of missing or not delivered units.

In this study, the participants were randomly selected from the pre-consultation pool taking into consideration that this is a pilot study.
Matrix 2

\begin{tabular}{|c|c|c|c|}
\hline Hotel Name & $\begin{array}{c}\text { Employees } \\
\text { No }\end{array}$ & $\begin{array}{c}\text { Target } \\
\text { Population }\end{array}$ & $\begin{array}{c}\text { Sample } \\
\text { Size } \\
\text { Needed }\end{array}$ \\
\hline Acapulco & 170 & & \\
Cratos Hotel & 180 & & \\
Kaya Artemis Resort & 120 & & \\
Malpas Hotel & 145 & & \\
Mercure Hotel & 80 & & \\
Merit Crystal Cove & 90 & & \\
Golden Tulip Lefkosa & 65 & & \\
Hotel & 90 & & \\
Rocks Hotel & 75 & & \\
Salamis Bey Conti & 85 & & \\
Savoy Hotel & 90 & & \\
The Colony Hotel & 90 & & \\
Vuni Palace Hotel & 90 & \\
\hline
\end{tabular}

\section{B. Questionnairy Design}

For the purpose of this study random probability sampling was selected. As Roscoe [20] cites in Sekaran [21], "sample sizes larger than 30 and less than 500 are appropriate for most research". Cohen [8] defines a questionnaire as a self-report instrument used for gathering information about variables of interest to an investigation. For this study, 47 questions categorized in four sections were modeled to verify the respondents to have an option among the questions. This type of survey can be easily employed among people of all ages and they are replicated from one subject to another and many questions can be answered in a short time [1]. 


\section{Participants and Size}

A total, 360 anonymous questionnaires were distributed through HR departments of the selected hotels, with a letter describing the aims and procedure of the study assuring that the survey was anonymous and no individual would be identified in analyzing and reporting the data. Thus, a minimum target group was identified that created a pool of $(n=360)$ participants through a questionnaire review. It finally yielded 303 completed forms.

\section{Measure Instruments}

It was proposed to develop a questionnaire consisting of four sections. For this aim, the following sections been considered:

- Social-Demographic Form;

- $\quad$ Negative Acts Questionnaire or (NAQ Scale);

\section{Socio-Demographic Form}

Socio-demographic form was developed with the purpose to analyze the demographic and social status of the respondents.

\section{Negative Acts Questionnaire}

Negative Acts Questionnaire (NAQ Scale) was used for analyzing the level of mobbing. Negative Acts Questionnaire was developed by Einarsen and Raknes in 1997 [14], originally consists of 22 items which aims to examine negative and potentially harassing behaviors experienced at workplace. The report scales the frequency of the negative behaviors within the last six months which formed into five-point Likert Scale to: (1) never, (2) sometimes, (3) every month, (4) every week, (5) everyday. Questions ask the level of harrasment of the victim.

Reliability analyses proved that the scale has high internal consistency and high test-retest and split half reliabilities. According to the findings, it was concluded that Turkish version of the NAQ has sufficiently high reliability and validity to justify its adaptation as a tool to measure workplace bullying in our research [4].

\section{E. Data Collection and Analysis Instruments}

In order to get a reliable data, Likert scale and reliability indication for Cronbach value has been accepted to be employed. Psychometric properties of the measures through KMO and Bartlett's Test are considered. SPSS statistical package of version 16 is aimed to be used through descriptive statistics in particular of data analysis (frequency, percentage, mean, standard deviation). Next, apart from descriptive, mean score was employed to explore average rate of responses. Additionally, T-test was proposed among the factors of questionnaires. It was also recommended to utilize EFA (exploratory factor analysis) with the aim to experiment the assumptions for issues of dimensionality and convergent validity. The EFA's aim is to find the factor or factors based on the relationships between the [16]. As stated by Conway et al., [9], it's beneficial if EFA acts as a considerable function when making research.

\section{Research Findings}

\section{A. Exploratory Factor Analysis}

Factor validity of the questionnaire was evaluated first by exploratory factor analysis (EFA), using the sample of 303 employees. Following the recommendations of Dziubna and Shirkey [11], before the analysis, we explored the psychometric adequacy of the items. Bartlett's (1950) sphericity test indicated that the items were dependent ( $p$ $<.0001)$, Bartlett's Test of Sphericity value was found $(\mathrm{df}=$ 703) so the result was acceptable, whereas the Kaiser-Meyer-Olkin Sampling Adequacy index [15], was higher than the recommended value of .50 (KMO = $0.870)>.70$ and significance level was $p=.00(<.05)$. (Table 1).

Table 1. KMO and Bartlett's Test

\begin{tabular}{|c|c|c|}
\hline \multicolumn{2}{|c|}{ Kaiser-Meyer-Olkin Measure of Sampling Adequacy. } & \multicolumn{1}{|c|}{, 870} \\
\hline \multirow{2}{*}{ Bartlett's Test of Sphericity } & $\begin{array}{c}\text { Approx. } \\
\text { Chi-Square }\end{array}$ & 4871,361 \\
\cline { 2 - 4 } & df & 703 \\
\cline { 2 - 3 } & Sig. &, 000 \\
\hline
\end{tabular}

Therefore, the data showed good sample adequacy and suitable correlations of the items, which indicates they were appropriate for factor analysis.

As we expected the factors to be related, factor analysis was performed for NAQ section using principle components and oblique rotation (oblimin Kaiser). The research applied the Kaiser criterion (Eigenvalue higher than 1) to extract the number of factors and to assign the items to the factors, we considered factor loadings equal to or higher than 0.40., [10]. Cattell's [7], scree test or sedimentation test clearly showed a two-factor test structure, which accounted for $82.97 \%$ of the total variance (Table 2 ).

The interpretability of the factor structures obtained suggested considering a two-factor structure as provisionally viable. Factor I comprised items 5, 6, 7, 8, 9, 12, 14, 15, 17, 20 which assess personal mobbing. Factor II grouped items 1 , 2, 3, 4, 10, 11,13, 16, 18 and 19, which evaluates mobbing behaviors involving attacks aimed at a person's private and personal life. The scale with the highest factor loading for personal mobbing was accounted for $40.79 \%$ of the total variance of the questionnaire, whereas the work-related mobbing factor is $42.18 \%$. Moreover, as can be seen in Table 2 , all the items of the scale presented high factor loadings, ranging between .46 and .69 . 
Table 2. Matrix of Factor Loadings for each Item $(\mathrm{N}=303)$

\begin{tabular}{|c|c|}
\hline Factor I: Personal Mobbing & variance: $40.79 \%$ \\
\hline Item Content & Item Loadings \\
\hline Spreading of gossip and rumors about you & .472 \\
\hline Being ignored, excluded or being "sent to Coventry" & .677 \\
\hline $\begin{array}{c}\text { Having insulting or offensive remarks made about your } \\
\text { person (i.e. habits and background), your attitudes or your } \\
\text { private life }\end{array}$ & .683 \\
\hline $\begin{array}{l}\text { Being shouted at or being the target of spontaneous anger (or } \\
\text { rage) }\end{array}$ & .446 \\
\hline $\begin{array}{l}\text { Intimidating behavior such as finger-pointing, invasion of } \\
\text { personal space, shoving, blocking/barring the way }\end{array}$ & .474 \\
\hline $\begin{array}{l}\text { Being ignored or facing a hostile reaction when you } \\
\text { approach }\end{array}$ & .427 \\
\hline Having your opinions and views ignored & .521 \\
\hline Practical jokes carried out by people you don't get on with & .639 \\
\hline Having allegations made against you & .484 \\
\hline Being the subject of excessive teasing and sarcasm & .499 \\
\hline Factor II: Work-Related Mobbing & variance: $42.18 \%$ \\
\hline Item Content & Item Loadings \\
\hline $\begin{array}{l}\text { Someone withholding information which affects your } \\
\text { performance }\end{array}$ & .584 \\
\hline Being humiliated or ridiculed in connection with your work & .696 \\
\hline Being ordered to do work below your level of competence & .630 \\
\hline $\begin{array}{l}\text { Having key areas of responsibility removed or replaced with } \\
\text { more trivial or unpleasant tasks }\end{array}$ & .544 \\
\hline Hints or signals from others that you should quit your job & .672 \\
\hline Repeated reminders of your errors or mistakes & .684 \\
\hline Persistent criticism of your work and effort & .486 \\
\hline $\begin{array}{l}\text { Being given tasks with unreasonable or impossible targets or } \\
\text { deadlines }\end{array}$ & .490 \\
\hline Excessive monitoring of your work & .524 \\
\hline $\begin{array}{c}\text { Pressure not to claim something which by right you are } \\
\text { entitled to (e.g. sick leave, holiday entitlement, travel } \\
\text { expenses) }\end{array}$ & .466 \\
\hline Being exposed to an unmanageable workload & .601 \\
\hline Threats of violence or physical abuse or actual abuse & .458 \\
\hline
\end{tabular}


Table 3. Demographic Characteristics

\begin{tabular}{lc}
\hline Gender & $N(\%)$ \\
Female & $110(36.3)$ \\
Male & $192(63.4)$ \\
Age & $105(34.7)$ \\
$20-30$ & $112(37.0)$ \\
$31-40$ & $71(23.4)$ \\
$41-50$ & $14(4.6)$ \\
$51-60$ & $1(0.3)$ \\
61 above & \\
Marital Status & $162(53.5)$ \\
Married & $118(38.9)$ \\
Single & $12(4.0)$ \\
Engaged & $8(2.6)$ \\
Divorced & $2(0.7)$ \\
Widow & \\
Nationality & $65(21.5)$ \\
Cyprus & $222(73.3)$ \\
Turkey & $12(4.0)$ \\
Different & \\
Educational Level & $23(7.6)$ \\
Primary School & $88(29.0)$ \\
Secondary School & $110(36.3)$ \\
High School & $80(26.4)$ \\
University & \\
Position & $40(13.2)$ \\
Administrative & $60(19.8)$ \\
Guest services & $176(58.1)$ \\
Guest services & $23(7.6)$ \\
Different & \\
Duration at Present Work & $50(16.5)$ \\
$0-1$ & $53(17.5)$ \\
1-3 & $96(31.7)$ \\
3-5 & $84(27.7)$ \\
10-10 & $20(6.6)$ \\
Total Duration of Work & \\
$0-1$ & $17(5.6)$ \\
$1-3$ & $33(10.9)$ \\
3-5 & $52(17.2)$ \\
5-10 & $106(35.0)$ \\
$10-$ & $95(31.4)$ \\
\hline & \\
\hline & \\
\hline & \\
\hline
\end{tabular}

Table 4. NAQ Perception

\begin{tabular}{lc}
\hline & $\mathrm{N}(\%)$ \\
\hline Non-victim & $176(58.1)$ \\
Victim & $127(41.9)$ \\
\hline
\end{tabular}

According to perception of victim or non-victim among respondents, it is seen that $58.1 \%(\mathrm{n}=176)$ of the participants perceived themselves as non-victim and $41.9 \%(\mathrm{n}=127)$ of them perceived themselves as victim.

Table 5. NAQ (Personal Mobbing)

\begin{tabular}{cccccc}
\hline & $\begin{array}{c}\text { Never } \\
\mathrm{n} \%\end{array}$ & $\begin{array}{c}\text { Now \& then } \\
\mathrm{n} \%\end{array}$ & $\begin{array}{c}\text { Monthly } \\
\mathrm{n} \%\end{array}$ & $\begin{array}{c}\text { Weekly } \\
\mathrm{n} \%\end{array}$ & $\begin{array}{c}\text { Daily } \\
\mathrm{n} \%\end{array}$ \\
\hline NAQ5 & $145(47.9)$ & $97(32.0)$ & $38(12.5)$ & $13(4.3)$ & $9(3.0)$ \\
NAQ6 & $150(49.5)$ & $93(30.7)$ & $43(14.2)$ & $12(4.0)$ & $5(1.7)$ \\
NAQ7 & $169(55.8)$ & $86(28.4)$ & $36(11.9)$ & $9(3.0)$ & $3(1.0)$ \\
NAQ8 & $152(50.2)$ & $92(30.4)$ & $41(13.5)$ & $9(3.0)$ & $8(2.6)$ \\
NAQ9 & $203(67.0)$ & $81(26.7)$ & $13(4.3)$ & $5(1.7)$ & $1(0.3)$ \\
NAQ12 & $170(56.1)$ & $85(28.1)$ & $32(10.6)$ & $8(2.6)$ & $8(2.6)$ \\
NAQ14 & $141(46.5)$ & $118(38.9)$ & $27(8.9)$ & $10(3.3)$ & $7(2.3)$ \\
NAQ15 & $150(49.5)$ & $108(35.6)$ & $33(10.9)$ & $7(2.3)$ & $5(1.7)$ \\
NAQ17 & $160(52.8)$ & $92(30.4)$ & $39(12.9)$ & $6(2.0)$ & $5(1.7)$ \\
NAQ20 & $164(54.1)$ & $96(31.7)$ & $29(9.6)$ & $5(1.7)$ & $9(3.0)$ \\
\hline
\end{tabular}


Table 6. NAQ (Work-Related Mobbing)

\begin{tabular}{cccccc}
\hline NAQ1 & $\begin{array}{c}\text { Never } \\
\mathrm{n} \%\end{array}$ & Now \& then $\mathrm{n} \%$ & $\begin{array}{c}\text { Monthly } \\
\mathrm{n} \%\end{array}$ & $\begin{array}{c}\text { Weekly } \\
\mathrm{n} \%\end{array}$ & $\begin{array}{c}\text { Daily } \\
\mathrm{n} \%\end{array}$ \\
NAQ2 & $155(53.5)$ & $123(40.6)$ & $8(2.6)$ & $2(0.7)$ & $8(2.6)$ \\
NAQ3 & $127(41.9)$ & $108(35.6)$ & $39(12.9)$ & $11(3.6)$ & $18(5.9)$ \\
NAQ4 & $142(46.9)$ & $99(32.7)$ & $37(12.2)$ & $17(5.6)$ & $8(2.6)$ \\
NAQ10 & $165(54.5)$ & $107(35.3)$ & $24(7.9)$ & $4(1.3)$ & $3(1.0)$ \\
NAQ11 & $142(46.9)$ & $111(36.6)$ & $33(10.9)$ & $7(2.3)$ & $10(3.3)$ \\
NAQ13 & $161(53.1)$ & $95(31.4)$ & $33(10.9)$ & $5(1.7)$ & $9(3.0)$ \\
NAQ16 & $129(42.6)$ & $113(37.3)$ & $45(14.9)$ & $8(2.6)$ & $8(2.6)$ \\
NAQ18 & $122(40.3)$ & $115(38.0)$ & $33(10.9)$ & $19(6.3)$ & $14(4.6)$ \\
NAQ19 & $148(48.8)$ & $98(32.3)$ & $30(9.9)$ & $16(5.3)$ & $10(3.3)$ \\
NAQ21 & $149(49.2)$ & $107(35.3)$ & $27(8.9)$ & $11(3.6)$ & $9(3.0)$ \\
NAQ22 & $176(58.1)$ & $82(27.1)$ & $34(11.2)$ & $7(2.3)$ & $4(1.3)$ \\
\hline
\end{tabular}

Table 7. One Sample T-Test

\begin{tabular}{lccc}
\hline \multicolumn{1}{c}{ Parameter } & $\mathrm{T}$ & $\mathrm{df}$ & Sig. (2-tailed) \\
\hline $\begin{array}{l}\text { Being ordered to do work below your } \\
\text { level of competence }\end{array}$ &,- 622 & 302 &, 635 \\
Excessive monitoring of your work &,- 476 & 302 &, 488 \\
$\begin{array}{l}\text { Pressure not to claim something which } \\
\text { by right you are entitled to (e.g. sick } \\
\text { leave, holiday entitlement, travel } \\
\text { expenses) }\end{array}$ &,- 695 & 302 & \\
\hline $\begin{array}{l}\text { P } \leq 0.05 \\
\end{array}$ & & &
\end{tabular}

T-Test indicates high significance which is correlated with the results received through frequency and description statistics. ANOVA analysis confirms no statistical difference was found for all 22 NAQ questions, advanced by analyzing with Turkey that finally confirmed no statistically significant difference.

\section{Conclusions}

The current research study highlighted that positive acts of mobbing behaviors occurred among employees in Northern Cyprus working in the field of tourism and hospitality. $41.9 \%$ of the participants perceived themselves as victim in Northern Cyprus. Also participants that indicated themselves as non-victims reported that they exposed to many forms of mobbing behavior in work place. As a matter of fact, it can be proposed that management style in the hospitality settings in Northern Cyprus creates reasons for his mismatch to which hospitality sector employees in Northern Cyprus are more seriously exposed to psychological mobbing.

The frequency and statistics results have accomplished by
SPSS-16 proved that mobbing occurs among employees that work in hospitality sectors in Northern Cyprus. The quality of current services provided by the HR function in the hotel organizations is poor and need to be addressed carefully by the HRM departments; management and HR performs more of administrative role than the strategic role. The review of the literature on HR theory and findings of research provided two valuable observations.

In a situation where an employee is constantly "mobbed" on the job, he/she has a form of alienation, depression and demotivation. The constant struggle for survival at work can cause frustration, stress, physical and mental illness. It should be noted that mobbing negatively impacts not only on the employee but also on the normal functioning of the company as a whole structure. Deterioration in the psychological climate within the organization leads to a sharp increase in turnover. Employees strive to find another place with a correct attitude towards staff. Involvement in the conflict interaction of team members lowers economic indicators of the organization. Increasing the risk of lawsuits by laid-off employees generates a negative reputation of the 
company. Research of mobbing in Northern Cyprus proved that employees at the hotel establishments significantly experienced mobbing. It can be believed that mobbing has higher rates, not amenable to statistical treatment. And in many cases after the employee has quitted the job or being fired, it may cause troubles related to health condition. However, the outcomes not only inter connected to the health of the individual but to a wider circle of related people, peers, relatives, friends which may have a serious impact on their lives. Another observation is that the existing correlation between employee's feedbacks and HR managers views allows to assume that there is a huge a gap of views among the employees and the HR department in considering mobbing in the hotel establishments where the majority of the HR practitioners claimed that mobbing rarely a new approach in nature and should be solved accordingly. Operation turnover is more significant in the view of one of the experts and there is no necessity to intervene into everyday social conflicts between the personnel. In order to prevent the psychological mobbing behaviors towards hospitality sector employees, particularly in Northern Cyprus, a number of measures should take place allowing more liberal management style by organizations and top managers; providing less official relations between personnel admitting organizational justice as a core approach, technical possibility to downsize work review and control and spread communication with employees by means of discussions, open (round) talks, professional awareness and trainings, evidently classifying the tasks and responsibilities and providing employees with significant health and insurance package.

\section{REFERENCES}

[1] Aaker D.A. and Day G.S. 1990. Marketing Research, New York: Wiley.

[2] Anderson, L. M., \& Pearson, C. M. (1999). Tit for tat? The spiraling effect of incivility in the workplace. Academy of Management Review, 24(3), 452-471.

[3] Aquino, K., Grover, S. L., Bradfield, M., \& Allen, D. (1999). The effects of negative affectivity, hierarchical status, and self-determination on workplace victimization. Academy of Management Journal, 42, 260-272.

[4] Aydın, O., Ocel, H. (2009). Isyeri Zorbalığı Olcegi: Gecerlik ve Guvenirlik Calısması. Turk Psikoloji Yazıları, 12(24), 94-103.

[5] Bennett, R. J., \& Robinson, S. L. (2000). Development of a measure of workplace deviance. Journal of Applied Psychology, 85, 349-360.

[6] Björkqvist, K., Österman, K., \& Hjelt-Bäck, M. (1994). Aggression among university employees. Aggressive Behaviour, 20(3), 173-184.

[7] Cattell, R.B. (1966). The Meaning and Strategic use of Factor Analysis. In R. Cattell (Ed.), Handbook of Multivariate
Experimental Psychology. Chicago: Rand McNally.

[8] Cohen, L., and Manion, L. 1989. Research Methods in Education. (Third ed.). London, England: Routledge.

[9] Conway, J. M., \& Huffcutt, A. I. (2003). A review and evaluation of exploratory factor analysis practices in organizational research. Organizational Research Methods, 6, $147-168$.

[10] Cliff, N., \& Hamburger, C.D. (1967). The Study of Sampling Errors in Factor Analysis by Means of Artificial Experiments. Psychological Bulletin, 68, 430-445.

[11] Dziuban, C.D., and Shirkey, E.C. (1974). When is a Correlation Appropriate for Factor Analysis? Some Decision Rules. Psychological Bulletin, 81, 358-361.

[12] Ford, J. ., MacCallum, R. C., and Tait, M. (1986). The Application of Exploratory Factor Analysis in Applied Psychology: A Critical Review and Analysis. Personnel Psychology, 39, 291-314.

[13] Einarsen, S., Hoel, H., Zapf D., \& Cooper, C.L. (2003). The concept of bullying at work: The European tradition. In S. Einarsen, H. Hoel, D. Zapf \& C. L. Cooper (Eds.) (2003). Bullying and emotional abuse in the workplace. International Perspectives in Research and Practice (pp 3-30). London: Taylor and Francis.

[14] Einarsen, S., Raknes, B.I., Matthiesen, S.B. (1994). Bullying and Harassments at Work And Their Relationship To Work Environment Quality: An Exploratory Study. European Work and Organizational Psychologist 4(4), 381-401.

[15] H.F. Kaiser. (1970) A second generation little jiffy. Psychometrika, 35(4):401-415.

[16] Keashly, L., \& Jagatic, K. (2003). By any other name. American perspectives on workplace bullying. In S. Einarsen, H. Hoel, D. Zapf \& C. L. Cooper (Eds.), Bullying and emotional abuse in the workplace. International Perspectives in Research and Practice (pp. 31-61). London: Taylor and Francis.

[17] Mars, H.W., Balla, J.R. and McDonald, R.P. (1988). Goodness of Fit Indexes in Confirmatory Factor Analysis: The Effect of Sample Size, Psychological Bulletin, 103(3), 391 - 410.

[18] Neuman, J. H., \& Baron, R. A. (2005). Aggression in the workplace: A social psychological perspective. In S. Fox \& P. E. Spector (Eds.), Counterproductive work behaviour (pp. 13-40). Washington, DC: American Psychological Association.

[19] Leymann, H. 1993. Mobbing Psychological Terror at Work, and How One Can Defend Oneself, Rowohlt, Reinbeck.

[20] TRNC Stat Agency, 2014; Tourism Office, 2012.

[21] Roscoe, J (1975). Fundamental Research Statistics for the Behavioral Sciences, 2nd Ed. New York: Holt, Rinehart and Winston.

[22] Sekaran, U. 2000. Research methods for business. A skill building approach, (3rd ed.) New York: Wiley.

[23] Spector, P. E. (2006). Method variance in organizational research. Truth or urban legend? Organizational Research Methods, 9(2), 221-232.

[24] WTO, (Tourism 2020 vision) Retrieved on August 19, 2013 
fromhttp://pub.unwto.org/WebRoot/Store/Shops/Infoshop/Pr oducts/1184/1184-1.pdf.

[25] Switzerland. WHO, Risks to Mental Health: an Overview of Vulnerabilities and Risk Factors, WHO Discussion Paper: 2012
[26] Yin, R.K. (2003) Case Study Research: Design and Methods (3rd ed., Vol. 5). Thousand Oaks, CA: Sage. 